\title{
The Principle of Humanization of the Criminal Policy in Russia in the Context of International Standards
}

\author{
Andrey V. Makarov \\ Doctor of Law, Professor, Transbaikal State University; jus-chita@yandex.ru
}

Sergey S. Zenin

\begin{abstract}
Candidate of Legal Sciences, Associate Professor, Constitutional and Municipal Law Department Kutafin Moscow State Law University, Russia, Senior Researcher, Russian Penitentiary Service Research Institute zeninsergei@mail.ru
\end{abstract}

\author{
Alexandra S. Zhukova \\ Master of Law, senior lecturer in criminal law and criminal procedure, Transbaikal State University \\ aleksa091987@yandex.ru
}

Doi:10.5901/mjss.2015.v6n6s4p134

\section{Abstract}

The article deals with a comprehensive analysis of the legal prescriptions of the Criminal Code of the Russian Federation aimed at the liberalization and humanization of the criminal policy in the context of international norms. The author examines the procedure of the imposition of a limit of the penalties for serious and very serious crimes. The content of the principle of humanization of the criminal policy is being considered. The article provides the discussion of the limits of acceptable change in mitigation of punishment and the author justifies the necessity to make legislative changes aimed at humanizing criminal legislation.

Keywords: state; criminal law; humanism; humanization; criminal policy; punishment.

\section{Introduction}

The aim of this research is to analyze legal prescriptions of the Criminal Code of the Russian Federation aimed at the liberalization and humanization of the criminal policy in the context of international norms. And the main objectives are (1) to examine the procedure of the imposition of a limit of the penalties for serious and very serious crimes; (2) to justify the necessity to make legislative changes aimed at humanizing criminal legislation.

Today, much legislative effort has been made to improve criminal law gaps formed in connection with the appearance of new forms and methods of committing crimes. There have been adopted a number of federal laws, aimed at improving the protection of the rights and freedom of citizens, transparency and access to justice, crime prevention, humanization of penalties. Moreover, lots of work has been done to decriminalize substantial corpora delicts, which do not meet the trends of development of the Russian Federation.

Significant changes have been made in the procedure of the imposition of a limit of the penalties for serious and very serious crimes. The content of the principle of humanism makes the protection of the person as the supreme value, the protection of his rights, freedom, honor and dignity, the interests of society from criminal attacks. On the other hand, it is the ratio of the offender, his sentence or other measures of criminal law, which can not be aimed at inflicting physical suffering or humiliation, of human dignity. But the main objective of criminal punishment is to restore social justice. Therefore, the limits of acceptable change in mitigation of punishment and legislative changes aimed at humanizing criminal legislation require further theoretical-ray examination and justification.

\section{Methodology}

When it comes to the study of any complex system or process for their components or parts, the lack of analytical studies in the future should be compensated by their synthetic study in a single, integrated system. Therefore, the research 
methodology is based on the facts, but they are so numerous that without their analysis, classification, and generalization it is impossible to anticipate the trends and development of the phenomena and processes of humanization of criminal policy in Russia. Thus, classification and systematization of facts is an important part of our scientific research. In the context of this article the facts refer to the legislative changes of the Criminal Code of the Russian Federation. The facts are represented in contrast with hypotheses and theories based on rational thinking and practice. We test hypotheses and theories providing accurate analysis of the facts, their classification and systematization, compiling and checking the data.

The research methodology is represented by the following methods: analysis, induction, comparison, dialectical method.

\section{The Meaning of Humanization of Criminal Policy}

The principles of the criminal policy of the Russian Federation and their performance provide a full implementation of the law and measures of criminal - legal sanctions in order to prevent crime and maintain national security.

The Criminal Code was developed when Russia was making its first independent steps to form a new state - the state of the market economy. Many of the criminal law issues were created while on a whim, according to the forecast of the development of not only the legal system of Russia, but also the whole society - of all its spheres. Those predictions were not always justified, and, if justified, to a large extent have already been exhausted, since the rapid change in inand inter-state relations within 18 years of the Criminal Code operation (Lopashenko, 2014). The whole strategy of criminal law and penal sectors in terms of demonstrative-humane management is primarily concerned with increasing the proportion of the importance of information on the identity of the perpetrator (Boiko, 2007).

The principle of humanization of criminal law is the gradual ennoblement of species and volume consumed means of combating crime. In science this is referred to as a visible prospect of the principle of economy of repression and involves the institutions of exemption from criminal liability and punishment, probation and parole, clemency appeal, etc. (Boiko, 2007).

The overall review shows that some authors define humanism as a principle that of not the criminal law, but as a principle of sentencing (Kälin, 1987; Boiko, 2007). According to Dyadyun (2013), "to overcome this contradiction requires a broader look at the content of the principle of humanism - from the object of criminal law protection".

Humanism as a universal human benevolent idea, which is based on the recognition of the individual as the highest social value of the society with a profound respect for his dignity and the utmost desire of the state to protect its rights, freedom and interests, creating conditions for human security and safe citizenship (Dyakov, 2013).

We agree with Chuchaev (2011) about the content of the principle of humanism as an approach to the identity of the person, his dignity and worth, with emphasis on the humanity of human relations.

The principle of humanization of the penal policy based on the rule of law and respect for human rights, improvement of the penalty of deprivation of liberty, etc., taking into account the fundamental principles is possible only if it finds its detailed reflection in the rules of law.

In a nutshell, the criminal law has undergone a large number of amendments and changes, but today we still need to talk about the ways to improve it. Obviously, a central place in the criminal policy of the Russian Federation is implementing the principles of the criminal law in order to restore social justice and national security of the state.

\section{Research Results}

Criminal policy of the Russian Federation is implemented through the application of regulatory requirements of federal law. The Criminal Code of the Russian Federation suggests a normative consolidation of the following principles: the rule of law, equality before the law, guilt, justice and humanism. Criminal - Executive Code establishes the normative content of the following principles: legality, equality of convicted persons before the law, democracy, humanism, individualization of criminal penalties, the differentiation of criminal penalties, the rational use of coercive measures and means of correcting the convicts (Art. 8 PEC RF). All of these principles are the basis of sector-specific legislation for the operation of the national system of criminal policy.

Obviously, the idea of humanism "permeated" the content of all criminal, criminal - executive, criminal - procedural law. Personality as a priority object of criminal - legal protection implies abiding citizens and criminals, too.

Thus, taking into account the age and psychological characteristics of persons who have not attained the age of majority, provided a significant softening of the measures applied to them according to the criminal law even up to the complete exemption from criminal liability. Article 6 of the Criminal Code "principle of humanity" states that punishment 
and other measures of criminal law applicable to a person who committed a crime may not have intended to cause physical suffering or humiliation of human dignity (Constitution of the Russian Federation, 1993).

Let's take a closer look and analyze how modern Russian criminal policy affects the implementation of the principle of humanism. Firstly, Part 4 of Art. 15 of the Constitution of the Russian Federation declares the Russian Federation as a subject of international law. Secondly, Art. 21 of the Constitution stipulates the dignity of the person protected by the state. Nothing can be a reason of his derogation. No one shall be subjected to torture or other cruel, inhuman or degrading treatment or punishment (Constitution of the Russian Federation, 1993).

It should be noted that the provision of international standards and the place that is given to international conventions in the national legal system, is a factor that contributes to the implementation of international treaty obligations. In this context, it should be noted that there are fundamental international norms implemented into national law defining the principles of humanization of the criminal policy of the Russian Federation. Article 5 of the Universal Declaration of Human Rights enshrines the following provision: "No one shall be subjected to torture or to cruel, inhuman or degrading treatment or punishment" (Universal Declaration of Human Rights, 1998). Article 3 of the Convention for the Protection of Human Rights and Fundamental Freedoms suggests "... Prohibition of torture. No one shall be subjected to torture or to inhuman or degrading treatment or punishment " (Convention for the Protection of Human Rights and Fundamental Freedoms, 1950). In Article 2 of the Declaration on the Protection of All Persons from Torture and Other Cruel, Inhuman or Degrading Treatment or Punishment in 1975 it is determined that any act of torture or other cruel, inhuman or degrading treatment or punishment is an offense to human dignity and it shall be condemned as a violation of the purposes of the United Nations Charter and the violation of human rights and fundamental freedoms proclaimed in the Universal Declaration of Human Rights (General Assembly Resolution 1975). The doctrinal content of the principle of humanism is reflected in the Convention against Torture and Other Cruel, Inhuman or Degrading Treatment or Punishment of 1989 and the Basic Principles for the Treatment of Prisoners and the UN Standard Minimum Rules in respect of non-custodial 1990 Minimum Standard Rules for the Treatment of Prisoners in 1955 and the European Prison Rules, 2006, and others. (UN Convention against Torture and Other Cruel, Inhuman or Degrading Treatment or Punishment, 1984). For example, p. 4 Art. 3 Criminal Enforcement Code suggests that the international legal instruments of Correction and Treatment of Prisoners, which is advisory in nature, are executed only under the necessary economic and social conditions. Full implementation of international recommendations in the penal legislation of the Russian Federation is possible only in the long term.

Today the legislators do considerable work to implement and enforce international norm. A number of federal laws and regulations have been adopted and aimed at improving the protection of the rights and freedoms of citizens, the humanization of criminal penalties. For example, February 26, 2015 the Ministry of Justice of the Russian Federation drafted a decree of the Government of the Russian Federation "On Medical Examination of Convicts, Submitted to the Release from Punishment due to Illness " based on the results of monitoring the enforcement of the legislation of the Russian Federation in the field of public health, serving a sentence of imprisonment, the results of which indicate the need to revise and expand the existing legislation (Draft Resolution of the Government of the Russian Federation "On Medical Examination of Convicts, Submitted to the Release from Punishment due to Illness ", 2015).

The goal of the humanization of law and practice is to optimize the process of selection and application of penalties most appropriate to the nature and degree of public danger of new manifestations of crime, taking into account the individual characteristics of the perpetrator and possible prospects for its correction. This goal remains an urgent task of law-making in the conduct of law enforcement policy and its scientific support (Kashepov, 2013).

Now we review some legislative changes in recent years and analyze how criminal policy can influence the practice of law with regard to criminal sentencing as a measure to restore social justice for the crimes.

Thus, by the Federal Act of 2011 \# 26 and \#420 there were established amendments and additions to the Criminal Code, "demonstrating" the humanization of the criminal law. It brought about a significant change in the content of its sections, such as Crime, Punishment, Exemption from Criminal Liability, giving rise to new concepts and burning issues in law enforcement sphere. In today's edition of p. 2 Art. 15 of the Criminal Code there have been changed the boundaries of categories of offenses. Minor offenses are considered deliberate and careless actions for committing of which the maximum punishment does not exceed three years imprisonment. Misdemeanor means deliberate and careless actions for committing of which the maximum punishment exceeds three years imprisonment. These rules provide an alternative to the court to change the category of the crime in the direction of leniency.

Kruglikov (2012) supposes this innovation is already causing criticism. In the absence of solution to the problem of establishing the limits of judicial discretion in the definition of crimes and to clearly define features of variable approach to sentencing, as well as more stringent procedural control by the higher courts, these new standards give birth to doubts about the objectivity of the judge's decision. The changes entail categories of difficulty in enforcement practice concerning 
the application of retroactivity of the Criminal Code. Accordingly, if the "new" criminal law tends to mitigate criminal penalties, it is subject to reduction within the modified rules (para. 2 of Article 10 of the Criminal Code). Thus, the following question may arise: what must the justice decide on the issue of exclusion of the lower limit of the sanctions in some articles of the Criminal Code of the Russian Federation, and of retraining act on the rate of the new edition, with the appointment of a more humane type of sanctions? Section "Punishment" in the modern version of p. 5, Art. 46 of the Criminal Code requires the replacement of the fine form of punishment other than imprisonment. This gives rise to the question of the proportionality of the criminal penalties of corpus delict of Art.204 "Commercial Bribery", Art.290 "Bribetaking", Art. 291 "Bribery" Art.291.1 "Intermediation in Bribery" of the Criminal Code. Under the application of Art. 50 of the Criminal Code "Correctional Labor", if the article provides the appointment of more severe forms of punishment than corrective work, should the use of corrective labor in the new edition be seen as improving the status of persons. Although, it appears that the expansion of the possibility of appointing corrective work may be seen as strengthening the case only punishable if corrective work is the most severe form of punishment under the article of the Criminal Code.

The stated above laws humanized the provisions on account of exemption from criminal liability and the application of the Criminal Code and the Code of Criminal Procedure of the crimes in the sphere of economic activity. In particular, the law contains provision on the termination of criminal prosecution. First-time offenders, under Art. Art. 198 - 199.1 of the Criminal Code, shall be exempt from criminal liability, if the damage to the budget system of the Russian Federation as a result of the offense, be refunded in full. A person who has committed a crime, shall be exempt from criminal liability if repair the damage caused to an individual, organization or government as a result of the crime, and transferred to the federal budget in the amount of monetary compensation to five times the amount of damage or transferred to the federal budget the income obtained as a result of crime, and a refund in the amount of five times the amount of income derived from the commission of the crime. These changes are related to business, bankruptcy, credit sphere and the sphere of mandatory payments (Part 1 of Art. 171, Part 1 of Art. 171.1, h. 1, Art. 172, h. 2, Art. 176, Art. 177, Part 12 Art. 180, § 3 , 4 Art. 184, Part 1 of Art. 185, Art. 185.1, Part 1 of Art. 185.2, Art. 185.3, Part 1 of Art. 185.4, Art. 193, h. 1 st.194, Art. Art. 195 - 197 and Art. 199.2 of the Criminal Code). But, according to the Criminal - Procedure Code prosecution terminated by the court, or investigator with the consent of the head of the investigation department, and the inquirer with the consent of the prosecutor. Therefore, the termination of criminal prosecution depends on the law enforcers.

Thus, the law expanded the powers of law enforcers, which will lead to the release of the accused and suspected of committing a crime. This reflects the humanization of law enforcement at the level of the Criminal - Procedure Code.

\section{Conclusion}

The states - participants of the international regulations implement the principle of humanism addressed to persons found guilty of a crime. In particular, the law prohibits the use of torture to them and other activities, especially causing physical suffering or degrading human dignity. Accordingly, in compliance with international practice, the principle of humanism is estimated primarily with respect to national law to the perpetrator. In Russia the content of "humanism" at the level of the criminal law is determined by the fact that the situation of the perpetrator is improved by the implementation of social and moral principles, expressed with the "compassionate" regard to a particular group of persons by criminal law.

Today, largely improved are the criminal law gaps formed in connection with the trends of new criminal forms and methods of committing crimes. Priority directions of criminal policy are implemented through a number of federal laws, which are aimed at improving the protection of the rights and freedom of citizens, transparency and access to justice, crime prevention, humanization of criminal penalties. Eighteen period of the Criminal Code operation in the Russian Federation and the application of its provisions shows that its adoption in 1996 the basic concept of criminal - legal doctrine and the reforms of the Russian criminal law were implemented.

The above analyzed law patterns are objective prerequisites of liberal and humane approach of the Russian legislator. But the current "state" of the criminal law, from the perspective of law enforcement trend suggests a disproportionate punishment for certain types of criminal manifestations of the social danger that prevail under the current levels of crime in Russia.

\section{References}

Boiko A.I. (2007). The moral and religious foundations of the criminal law. Rostov n / D, pp.157-159.

Chuchaev A.I. (2011). Comment to the Criminal Code of the Russian Federation. Moscow: CONTRSACT Law Firm, pp.146-148.

Convention for the Protection of Human Rights and Fundamental Freedoms, ETS N 005 (1950). Bulletin of International Agreements, \# 7.

Draft Resolution of the Government of the Russian Federation "On medical examination of convicts, submitted to the release from 
punishment due to illness" (2015). http://www.garant.ru.

Dyakov S.V. (2013). Comment to the Criminal Code of the Russian Federation. Moscow: Jurisprudence, pp.100 - 103.

Dyadyun K.V. (2013). The implementation of the principle of humanism in law and enforcement. Russian Legal Journal Vol 1, pp.1-3.

Kashepov V.P. (2013). The transformation of the institute of general criminal law through additional legislation. Journal of Russian Law, pp.17-19.

Kashepov V.P. International legal standards in the criminal justice system of the Russian Federation: scientific and practical guide. Moscow: Institute of Legislation and Comparative Law under the Government of the Russian Federation, p.16.

Kälin, SG (1987). The principles of the Criminal Code. Moscow: Yurayt-izdat, p.27.

Kruglikov L.L. (2012). Changes in criminal law (December 2011): evidence for its further development or stagnation. Actual problems of criminal law and criminology at the present stage. Vol. 1. Yaroslavl: Logos, pp.11-12.

Lopashenko N.A. (2014). On the doctrinal background of the new criminal law. Criminological Magazine, Baikal State University of Economics and Law, pp.5-13.

The Constitution of the Russian Federation (1993). Collection of Laws of the Russian Federation. Art. 4398.

The Universal Declaration of Human Rights (1948). Russian newspaper, pp.10 -16.

The UN Convention against Torture and Other Cruel, Inhuman or Degrading Treatment or Punishment (1984). Existing international law. Volume 3, p.3.

UN General Assembly Resolution (1975) - http: // www. garant.ru 